Article

\title{
Long-Term Effects of Mercury on Biofilms Grown in Contaminated Microcosms: A Pilot Study
}

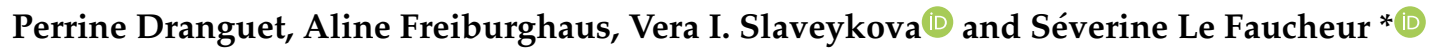 \\ Faculty of Sciences, Section of Earth and Environmental Sciences, Department F.-A. Forel for Environmental and \\ Aquatic Sciences, Environmental Biogeochemistry and Ecotoxicology group, University of Geneva, \\ Uni Carl Vogt, 66 Blvd Carl-Vogt, CH 1211 Geneva, Switzerland; perrine.dranguet@sfr.fr (P.D.); \\ aline.freiburghaus@gmail.com (A.F.); vera.slaveykova@unige.ch (V.I.S.) \\ * Correspondence: severine_lefaucheur@hotmail.fr
}

Received: 14 December 2018; Accepted: 19 February 2019; Published: 26 February 2019

\begin{abstract}
Biofilms are important components of the mercury $(\mathrm{Hg})$ biogeochemical cycle. However, $\mathrm{Hg}$ effects on biofilm communities are overlooked. Here, we present results of a pilot study on the chronic effects of $\mathrm{Hg}$ on biofilms, notably on the potential change of their taxonomic composition. Biofilms were cultivated in microcosms enriched with three different $\mathrm{Hg}$ concentrations ( $11 \pm 2 \mathrm{pM}$, $121 \pm 9 \mathrm{pM}$ and $1454 \pm 54 \mathrm{pM}$ ) for 55 days and examined for their accumulated $\mathrm{Hg}$ concentrations and composition. Bioaccumulated $\mathrm{Hg}$ concentrations were representative of those encountered in natural environments. Despite the lack of influence on the ash free dry weight and chlorophyll content, the surface coverage of the substrata of biofilms grown in $\mathrm{Hg}$ decreased. Algal community were strongly affected by $\mathrm{Hg}$, with a decrease in their richness with Ochrophyta found as the most sensitive phyla. The diversity and richness of bacterial communities did not change upon cultivation in $\mathrm{Hg}$ but the presence of Proteobacteria increased with $\mathrm{Hg}$, whereas Bacteroidetes, Actinobacteria, Verrumicrobia, and Cyanobacteria were negatively impacted. Overall, the above findings suggest that the examination of the algal community composition might be used as a potential biomonitoring tool to assess the impacts of environmental $\mathrm{Hg}$ concentrations on aquatic systems, which would merit further investigation.
\end{abstract}

Keywords: periphyton; bioaccumulation; taxonomy; methylmercury; bacteria; microalgae

\section{Introduction}

Freshwater biofilms are communities of microorganisms living in the substrata (rocks, plants, sediments), which play an important role in the ecology and biochemistry of streams [1]. Microalgae composing biofilms are the main primary producers of running and shallow waters, with a biomass representing between 42 to $97 \%$ of the total annual productivity of shallow lakes [2,3]. The biotic fraction of biofilms is also composed of heterotroph organisms (fungi and bacteria), which live in symbiosis with microalgae and interlocked in a matrix of extracellular polymeric substances (EPS). As such, that natural assemblage of organisms is an important component of both microbial and phototrophic aquatic food webs [4]. In ecotoxicology, biofilms are considered as good bioindicators of water quality impairment. Indeed, they can be found in several types of ecosystems (lakes, rivers, wetlands, flood plain etc.,), whereas they possess interesting features, such as a short generation time and a diversity in their microbial composition, which quickly responds and integrates changes of environmental conditions $[5,6]$.

Anthropogenic mercury $(\mathrm{Hg})$ emissions have long been identified as highly disruptive for its natural biogeochemical cycle $[7,8]$. Furthermore, $\mathrm{Hg}$ is a global pollutant and priority hazardous substance due to its high toxicity and the biomagnification of its methylated forms ( $\mathrm{MeHg}$ ), a 
potent neurotoxin, along the food chains. The numerous interactions between $\mathrm{Hg}$ compounds and biofilms have been recently comprehensively reviewed, with a specific emphasis on $\mathrm{Hg}$ availability, transformations and effects towards freshwater biofilms [9]. Biofilm organisms are also known to be one of the pathway entries of inorganic $\mathrm{Hg}$ ( $\mathrm{IHg}$ ) and $\mathrm{MeHg}$ into aquatic food webs $[10,11]$. They are recognized to participate in the transformations of $\mathrm{Hg}$ in natural waters. Indeed, bioaccumulated $\mathrm{IHg}$ has been demonstrated to be reduced into its elemental $\mathrm{Hg}^{0}$ form by biofilms [12] as well as methylated by inhabiting sulfate-reducing bacteria, iron-reducing bacteria, and methanogens whereas demethylation of $\mathrm{MeHg}$ has been also shown to occur [13-15].

In turn, the functionality and structure of biofilms have been described to be the target of contaminants [5]. In the case of $\mathrm{Hg}$, exposure studies performed with environmental biofilms under controlled conditions are scarce. The density of diatoms harbored in biofilms exposed for 34 days to $2.3 \mathrm{nM}$ and $9 \mathrm{nM}$ of $\mathrm{MeHg}$ was measured to be 2.5 and 6 times lower than the one of non-exposed biofilms, respectively [16]. That phenomenon was accompanied by a decrease of the microalgae cell size whereas a shift from sensitive to more tolerant species was also observed with the decrease of Navicula aquaedurae and with the increase of both Nitzschia palea and Fallacia pygmaea abundance. Three communities of biofilms collected at different sites along the Gallego River (Spain) and exposed to $\mathrm{Hg}$ in microcosms for a short period of time $\left(1 \mathrm{~h}\right.$ and $2 \mathrm{~h}$ ) had $\mathrm{EC}_{50}$ values varying between $0.7 \mu \mathrm{M}$ and $3.6 \mu \mathrm{M}$ for the most sensitive population and between $100 \mu \mathrm{M}$ and $200 \mu \mathrm{M}$ for the least sensitive [17]. In agreement with these studies, a shift in bacterial and microalgal communities upon $\mathrm{Hg}$ exposure were also evidenced in the field. That change was observed in biofilms exposed to $\mathrm{Hg}$ in mine-impacted rivers with the increase of the abundance of mer $A$ (a gene encoding for a protein able to reduce $\mathrm{IHg}$, process involved in bacteria $\mathrm{Hg}$ tolerance) with the increase of bioaccumulated $\mathrm{Hg}$ [18]. A similar pattern was observed in biofilms collected in reservoirs contaminated by industrial $\mathrm{Hg}$ release [19]. Algal species shift was demonstrated in the Gallego River with the higher abundance of the filamentous algae Oedognium and Stigeoclonium in biofilms living at the most contaminated site ( $70 \mathrm{pM} \mathrm{Hg}$ ), suggesting that both species could be tolerant to Hg [17]. In the Olt River (Romania) under the influence of chlor-alkali plant effluents, the dominant species in the biofilm communities were the Cyanobacteria for algae, Bacillariophyta for algae, and Taphrinomycetes for fungi [20].

Nonetheless, in the above field studies, several environmental confounding factors such as current, light or the presence of other contaminants could modulate $\mathrm{Hg}$ accumulation in biofilms as well as their composition, limiting the possibility to accurately demonstrate the relationship between $\mathrm{Hg}$ contamination and impacts towards biofilm composition. The goal of the present study was thus to bring first insights on the long-term effects of $\mathrm{Hg}$ exposure on biofilm growth (biomass) and taxonomic composition.

\section{Materials and Methods}

\subsection{Labware Cleaning}

To avoid contamination of samples by $\mathrm{Hg}$ and microorganisms, microscopy glass slides and glass beakers were pyrolysed at $475^{\circ} \mathrm{C}$. All plastic ware, including exposure tanks, were cleaned using four successive baths containing soap, $10 \%$ nitric acid (two times) $\left(\mathrm{HNO}_{3}\right.$ pro-analysis, Merck, Darmstad, Germany) and $10 \%$ hydrochloric acid ( $\mathrm{HCl}$ pro-analysis, Merck, Darmstad, Germany). Proper rinsing with MilliQ water (<18 M $\Omega$, Millipore, Darmstadt, Germany) was performed between each step.

\subsection{Biofilm Culture in Hg-Enriched Microcosms}

Biofilms were grown on glass microscope slides $(7.6 \mathrm{~cm} \times 2.6 \mathrm{~cm})$ in four distinct plastic microcosms containing 7.5 L of Geneva Lake water (no pre-treatment) with and without $\mathrm{Hg}$ addition for 55 days. Three of the microcosms were enriched with $\mathrm{Hg}$ (stock solution concentration $1 \mathrm{~g} \mathrm{~L}^{-1}$ of $\mathrm{Hg})$ to reach the final measured concentrations of $11 \pm 2 \mathrm{pM}, 121 \pm 9 \mathrm{pM}$ and $1454 \pm 54 \mathrm{pM}(n=6)$ whereas one microcosm was not contaminated with $\mathrm{Hg}$ and kept as a control. One hundred slides 
(10 slides were placed vertically into 10 polypropylene (PP) baskets) were placed into each microcosm as growing supports. During the first 33 days, exposure media were renewed $(7.5 \mathrm{~L})$ twice a week to maintain stable $\mathrm{Hg}$ exposure concentrations and to amend microcosms with microorganisms. Indeed, the substrata were not colonized prior to the experiments, thus that biofilms were only cultivated in $\mathrm{Hg}$. After that period, i.e., once substrata were colonized with a thin layer of biofilms, and up to the end (55 days), water was not entirely changed but a small quantity of water was added every 3.5 days to balance with the evaporation and $\mathrm{Hg}$ was additionally spiked into $\mathrm{Hg}$ enriched-microcosms. That 55 days-period allowed us to work with a sufficient amount of biofilms for bioaccumulation measurements while being able to perform microscopic measurements. Biofilms developed under $1000 \mathrm{~lx}$ of light with a light:dark cycle of $16: 8 \mathrm{~h}$ and a temperature at $20 \pm 2{ }^{\circ} \mathrm{C}$. Water was continuously mixed with a submerged pump at $1 \mathrm{~L} \mathrm{~min}^{-1}$.

\subsection{Determination of the Water Quality Variables}

Water temperature and $\mathrm{pH}$ were measured with a $\mathrm{pH}$-meter (780 Metrohm, Herisau, Switzerland). For the determination of the major anion and cation concentrations, $10 \mathrm{~mL}$ of water was filtered at $0.45 \mu \mathrm{m}$ with Sterivex filters (poly(ether)sulfone, Millipore, Schaffhausen, Switzerland) in PP tubes and measured with ion chromatography (Dionex ICS-3000, Thermo Fisher Scientific Inc., Waltham, MA, USA). Another $10 \mathrm{~mL}$ of water was further filtered and acidified to $2 \% \mathrm{HNO}_{3}$ (suprapur, Darmstadt, Germany) and analyzed for their dissolved trace metals $(0.45 \mu \mathrm{m}$ filterable, $\mathrm{Cr}, \mathrm{Ni}, \mathrm{Cu}, \mathrm{Zn}, \mathrm{As}, \mathrm{Mo}$, $\mathrm{Cd}, \mathrm{Pb}, \mathrm{Se}$, and $\mathrm{Co}$ ) concentrations by inductively coupled plasma mass spectrometry (ICP-MS; Agilent 7700, Morges, Switzerland). Additionally, $50 \mathrm{~mL}$ were collected in $550{ }^{\circ} \mathrm{C}$ burned glass bottles, after filtration on pre-pyrolysed $0.7 \mu \mathrm{m}$ GF/F filters (GE Healthcare Life Sciences, Glattbrugg, Switzerland) and acidified to $2 \mathrm{M} \mathrm{HCl}$ (Ultrex, J.T. Baker, VWR, Nyon, Switzerland) to be analyzed for the dissolved organic carbon (DOC) concentrations with a Shimatzu TOC-5000 (Kyoto, Japan). The above measurements were all performed in triplicate. Water samples for the analysis of the dissolved $\mathrm{Hg}$ concentrations [THg] were collected at the beginning of the experiments (day 0), after 5 days exposure (before $\mathrm{Hg}$ spike), after 33 days exposure (after the $\mathrm{Hg}$ spike) and after 50 days exposure (at the end of exposure). For each sampling, $125 \mathrm{~mL}$ of water was filtered with $0.45 \mu \mathrm{m}$ Sterivex filters, acidified to $1 \%\left(v / v\right.$ final concentration) with $\mathrm{HCl}$ (Ultrex, J.T Baker ${ }^{\circ}, \mathrm{VWR}$, Nyon, Switzerland) and stored in $475^{\circ} \mathrm{C}$-burned glass bottles. [THg] were analyzed by cold vapor atomic fluorescence spectrometry (CV-AFS) with a MERX Automated Analytical System (Brooks Rand Instruments, Seattle, WA, USA) following the USEPA 1631 method [21]. The detection limit of the technique was $1.8 \mathrm{pM}$ (3 standard deviations of 10 blank measurements) and the certified reference material was the ORMS-5 (National Research Council Canada).

\subsection{Measurements of Accumulated $\mathrm{Hg}$ in Biofilms}

For each microcosm, six slides colonized by biofilms were sampled after 50 days of $\mathrm{Hg}$ exposure and analyzed for their total accumulated $\mathrm{Hg}\{\mathrm{THg}\}$, their non-extractable total $\mathrm{Hg}\{\mathrm{THg}\}_{\text {n-ext }}$, inorganic $\mathrm{Hg}\{\mathrm{IHg}\}_{\text {n-ext }}$ and methyl $\mathrm{Hg}\left\{\mathrm{MeHg}_{\text {n-ext }}\right.$ concentrations [19]. $\{\mathrm{THg}\}$ is the total accumulated $\mathrm{Hg}$ content $(\mathrm{THg}=\mathrm{IHg}+\mathrm{MeHg})$, which represents the sum of $\mathrm{Hg}$ adsorbed onto organisms, particles and matrix plus $\mathrm{Hg}$ absorbed by microorganisms. To determine $\{\mathrm{THg}\}$, slides were rinsed three times with $0.2 \mu \mathrm{m}$ filtered Geneva Lake water, scraped and were collected in pre-cleaned PP tubes. For the determination of the non-extractable concentrations, colonized slides were rinsed with $100 \mathrm{mM}$ cysteine (>97\%, sigma-Aldrich, Busch, Switzerland) for $10 \mathrm{~min}$, scraped, and stored in pre-cleaned PP tubes. The Hg content obtained with and without the cysteine-rinsing step were analyzed with an advanced Hg Analyzer (AMA) 254 (Altec s.r.l, Dvi̊r Králové nad Labem, Czech Republic), which has a detection limit of $0.03 \mathrm{ng}$ (3 SD of 3 blanks). The TORT2 and MESS3 (National Research Council, Canada) were both used to verify the accuracy of the AMA measurements. The measurements were accepted only when their expected concentrations were in the range of the certified materials. $\{\mathrm{MeHg}\}_{\mathrm{n} \text {-ext }}$ was first extracted with dichloromethane from biofilms following the method previously described 
in reference [19] to be measured with a MERX-M Automated Methylmercury System (Brooks Rand, Seattle, WA, USA). The detection limit of the technique was measured at $4.4 \mathrm{nM}$ and the certified reference material ERMCC5580 estuarine sediment was used to verify the accuracy of the extraction and measurements.

\subsection{Biofilm Characterization}

Biofilm biomass was assessed with the measurements of both the chlorophyll content $\left(\mathrm{ng} \mathrm{cm}{ }^{-2}\right.$ ) and the ash free dry weight (AFDW- $-\mu \mathrm{g} \mathrm{cm}^{-2}$ ). For each treatment, six microscopy glass slides were scraped and stored in three Eppendorf tubes at $-80^{\circ} \mathrm{C}$ and lyophilized for $24 \mathrm{~h}$. The chlorophyll was extracted using acetone to be further analyzed with a spectrophotometer HeLIOS $\mathrm{g}$ (Thermo Scientific, Reinach, Switzerland) [22]. The dry weight was measured after drying the samples at $60{ }^{\circ} \mathrm{C}$ for $48 \mathrm{~h}$ and AFDW was determined after an additional combustion step at $500{ }^{\circ} \mathrm{C}$ for $2 \mathrm{~h}$ using $3 \times 6$ slides.

The methods to determine the surface coverage of the substrata as well as the biotic and abiotic fractions of the biofilms have been described elsewhere [19]. Briefly, the biotic fraction was obtained after a staining of the biofilms with the probe 6-diamidino-2-phenylindodihydrochloride (DAPI) and their observation with a fluorescence microscope (Olympus BX61, Olympus, Volkestwil, Switzerland) using the DAPI channel. The percentage of the non-covered slide area (NCA) of the DAPI-stained biofilms was also determined using the DAPI channel, from which the percentage of the surface covered area was calculated by subtracting 100 to NCA. Biofilms without staining were observed in the channel DAPI to quantify the abiotic fractions (proxy of inorganic particles). Ten pictures were taken and analyzed with the software "ImageJ" to distinguish the fractions as a function of the hue, saturation, and brightness of the pictures [23].

Amplicon sequencing was performed to investigate the bacterial and microalgal composition. For each microcosm, biofilm ( 10 mg) was collected and stored in Eppendorf tubes at $-80^{\circ} \mathrm{C}$. The biofilm DNA were extracted using the Power Biofilm DNA kit (Mo-Bio, Carlsbad, CA, USA) and according to the provider instructions. Total DNA was quantified with a Qubit 2.0 fluorimeter (Invitrogen, Thermo Fisher Scientific, Waltham, MA, USA). The pair primers 1053F (5'- GCATGGCYGYCGTCAG-3'), 1319R (5'-CGACGCCATCTTCATTCACAT-3') and D512F (5'-ATTCCAGCTCCAATAGCG -3'), D978R (5'-GACTACGATGGTATCTAATC-3') were used as in our previous study [20]. These primers were selected to determine major bacterial and microalgal phyla [24,25]. Biofilms DNA were sent and analyzed with the Roche 454 FLX sequencer by "Research and testing laboratory" (Lubbock, TX, USA). For each condition, the OTU (Operational Taxonomic Unit) richness, the rarefied richness, the Simpson's diversity index and the turnover of each biofilm were calculated to assess the richness and diversity of the bacterial and algal communities $[20,26]$. The obtained sequences of microalgae and bacteria were submitted in the GenBank database under the sequence read archive (SRA) section with the following numbers: SRP131223 [27].

\subsection{Statistics}

Statistical analyses were performed on the log values of the mean $\{\mathrm{THg}\}$ and $\{\mathrm{IHg}\}_{\mathrm{n} \text {-ext }}$ and on the mean values of $\{\mathrm{MeHg}\}_{n-e x t}$, chlorophyll concentration and AFDM. The normality and homogeneity of their variances were tested with the Shapiro-Wilk and Bartlett tests, respectively. The significant differences between each treatment were assessed using a one-way ANOVA (Analysis of Variance) followed by the Tukey's HSD (Honestly Significant Difference) test. Rarefaction curves, species and rarefied richness, and Simpson's diversity index were obtained with the package Vegan [28]. The OTUs presence-absence were represented with Venn diagrams [29]. The software R was used to perform the statistical analyses [30]. 


\section{Results and Discussion}

\subsection{Biofilm Culture Conditions}

Culture media, which were composed of Geneva Lake water enriched with $\mathrm{Hg}$, were characterized by a $\mathrm{pH}$ value of $8.2 \pm 0.2$, a DOC concentration of $1.4 \pm 0.2 \mathrm{mg} \mathrm{L}^{-1}$ and a Ca ${ }^{2+}$ concentration of $1.14 \pm 0.03 \mathrm{mM}$ (Table S1). The measured trace metal concentrations were low, with a $\mathrm{Cu}$ and $\mathrm{Zn}$ concentrations of $8.09 \pm 0.49 \mathrm{nM}$ and $9.55 \pm 0.78 \mathrm{nM}$, respectively. These levels of the nutrients are in accordance with the mesotrophic, with a low-eutrophic tendency, condition of the Lake Geneva [31] and was thus appropriate to serve as a culture media, in which the presence of high concentrations of pollutants was not expected. The addition of $\mathrm{Hg}$ into the microcosms allowed us to obtain three dissolved culture $\mathrm{Hg}$ concentrations, i.e., $11 \pm 2$ pM, $121 \pm 9$ pM, and $1454 \pm 54$ pM dissolved Hg. A factor of approximately 10 was used between each studied concentration, with the first two studied $\mathrm{Hg}$ concentrations representing those measured in freshwater lakes, $121 \mathrm{pM}$ being found in rather highly contaminated systems [32]. After 5 days of cultivation, almost all $\mathrm{Hg}$ in solution was depleted (Figure S1). That phenomenon was possibly due to a combination of adsorption to microcosm walls and biofilm supports, volatilisation under $\mathrm{Hg}^{0}$ form, and bioaccumulation, which was overcome with the renewing of the culture media or with its $\mathrm{Hg}$ spiking.

\subsection{Hg Accumulation by Biofilms}

The cultivation of biofilms in $\mathrm{Hg}$ led to the increase of bioaccumulated $\mathrm{Hg}$ (Figure 1I) as compared with the unexposed control biofilm. Biofilms grown in the control microcosm already contained a natural background of $332 \pm 17 \mathrm{pmol} \mathrm{g}_{\mathrm{dw}}{ }^{-1}$ of $\{\mathrm{THg}\}$. Comparable $\{\mathrm{THg}\}$ was found in biofilms grown in $11 \mathrm{pM} \mathrm{Hg}(p=0.05 ; n=3)$ whereas at $121 \mathrm{pM} \mathrm{Hg}$ and $1454 \mathrm{pM} \mathrm{Hg}$, $\{\mathrm{THg}\}$ was 2.2-times and 25-times higher than the one measured in control biofilms, respectively. The natural $\{\mathrm{THg}\}$ background measured in the present study is in good agreement with those previously measured in biofilms grown in Geneva Lake, in which $\{\mathrm{THg}\}$ was found to vary between 86 and 214 pmol.gdw ${ }^{-1}$ depending on the biofilm age [22]. Measured $\{\mathrm{THg}\}$ in biofilms collected in various Hg-impacted rivers range in a wide range between $269 \mathrm{pmol}$ to $1.7 \mu \mathrm{mol} \mathrm{g}_{\mathrm{dw}}{ }^{-1}$ [9]. The extremely high concentration of $1.7 \mu \mathrm{mol} \mathrm{g} \mathrm{dw}^{-1}$ of $\{\mathrm{THg}\}$ was measured in biofilms collected in the Idrijca River (Slovenia), close to a former Hg mine, where high concentrations of dissolved $\mathrm{Hg}\left(272 \mathrm{ng} \mathrm{L}^{-1}\right)$ were measured [33]. The present studied biofilms are thus situated at the lower end of $\mathrm{Hg}$ bioaccumulation globally measured, suggesting that $\mathrm{Hg}$ is most probably not of concern for the water quality of the Geneva lake water surrounding our water sampling site, in agreement with the very low measured dissolved $\mathrm{Hg}$ concentrations.

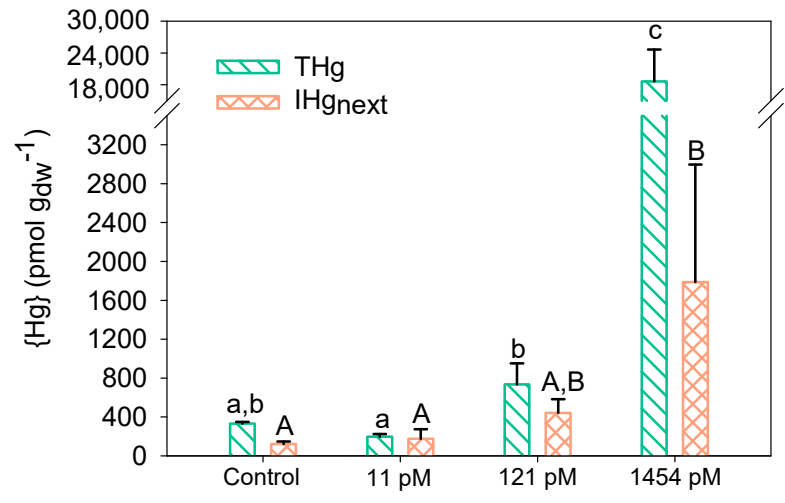

(I)

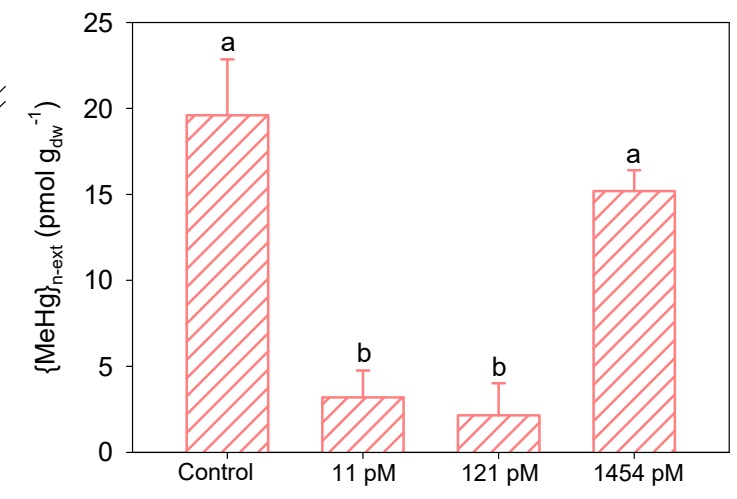

(II)

Figure 1. Concentrations of (I) total $\mathrm{Hg}$ and non-extractable $\mathrm{IHg}(n=3)$, and (II) non-extractable $\mathrm{MeHg}$ $(n=3)$ as a function of the measured dissolved $\mathrm{Hg}$ concentrations. Letters (a, b, c and A, B) indicate significant differences between treatments for the studied characteristics $(p<0.05)$. 
Comparing $\mathrm{Hg}$ accumulation between biofilms to infer conclusions on the quality of their ambient water should, however, be taken with caution. Indeed, $\mathrm{Hg}$ accumulation is not only dependent on the concentration of $\mathrm{Hg}$ in the ambient water but also of their surrounding environmental parameters (substrata, light, current, temperature), water chemical variables ( $\mathrm{pH}$ and DOC concentration), and composition [9]. Indeed, taxonomic composition and biofilm thickness were recently shown to modulate $\mathrm{Hg}$ uptake kinetics in freshwater biofilms [22]. Moreover, in contrast with other metals such as $\mathrm{Cu}, \mathrm{Zn}, \mathrm{Pb}$ or $\mathrm{Cd}, \mathrm{Hg}$ could be further transformed by biofilms and be excreted under its methylated and elemental form. Such processes would decrease accumulated $\mathrm{Hg}$ and led to a misinterpretation of accumulated $\mathrm{Hg}$ values. Further studies are needed to identify and quantify the extent with which such processes take place in biofilms grown under our experimental conditions.

The measurement of the total accumulated $\mathrm{Hg}$ in biofilms included $\mathrm{Hg}$ adsorbed to particles and microorganisms, $\mathrm{Hg}$ bound to the EPS matrix and $\mathrm{Hg}$ intracellularly taken up by biofilms. Applying a rinsing-step with cysteine allowed us to remove the non-specifically bound $\mathrm{Hg}$ and to get closer to the actual $\mathrm{Hg}$ (intracellular) concentration that would impact the microbial communities. In the present study, $\{\mathrm{IHg}\}_{\mathrm{n} \text {-ext }}$, proxy of the intracellular fraction, measured in the control biofilm represented $39 \%$ of $\{\mathrm{THg}\}\left(130 \pm 27 \mathrm{pmol} \mathrm{g} \mathrm{dw}^{-1}\right)$. Similar $\{\mathrm{IHg}\}_{\text {n-ext }}$ was observed upon cultivation in $11 \mathrm{pM} \mathrm{Hg}$ with the percentage of $\{\mathrm{IHg}\}_{n-e x t}$ being $89 \%\left(176 \pm 98 \mathrm{pmol} \mathrm{g}_{\mathrm{dw}}{ }^{-1}\right)$. At $121 \mathrm{pM} \mathrm{Hg}$ and $1454 \mathrm{pM}$, $\{\mathrm{IHg}\}_{\text {n-ext }}$ increased 3.9-times (non-significant) and 22.5-times $\left(2.7 \pm 1.2 \mathrm{nmol} \mathrm{g}_{\mathrm{dw}}{ }^{-1}\right)$, respectively. Interestingly, the fraction of $\{\mathrm{IHg}\}_{n \text {-ext }}$ as compared to $\{\mathrm{THg}\}$ decreased up to $14 \%$ at the higher $\mathrm{Hg}$ concentration (that percentage is $65 \%$ for biofilms grown in $121 \mathrm{pM} \mathrm{Hg}$ ). These measured $\{\mathrm{IHg}\}_{\text {n-ext }}$ in control and $\mathrm{Hg}$-cultivated biofilms were found to be comparable with those measured in biofilms grown in $\sim 150 \mathrm{pM} \mathrm{Hg}$ for $24 \mathrm{~h}$ (between $886 \mathrm{pmol} \mathrm{g}_{\mathrm{dw}}{ }^{-1}$ and $1.6 \mathrm{nmol} \mathrm{g}_{\mathrm{dw}}{ }^{-1}$ ) [22] and collected in a chlor-alkali impacted river (between $167 \mathrm{pmol} \mathrm{gdw}^{-1}$ (control reservoir) and $1 \mathrm{nmol} \mathrm{gdw}^{-1}$ (highly affected reservoir) [19]. The decrease of $\{\mathrm{IHg}\}_{\text {n-ext }}$ proportion as compared to $\{\mathrm{THg}\}$ with the increase of $\mathrm{Hg}$ in the culture media might be the result of the microbial community response to $\mathrm{Hg}$ exposure. Indeed, at the highest $\mathrm{Hg}$ concentration, microorganisms might have developed strategies to cope with higher ambient $\mathrm{Hg}$ concentration and thus accumulation. They might have regulated their metal transporters to limit Hg uptake [34]. They might also have formed larger amounts of EPS or modified their EPS synthetized structure to more efficiently sequestered $\mathrm{Hg}$ [35]. Finally, the culture conditions might have changed the microbial species communities with microbes less prone to accumulate $\mathrm{Hg}$ (see Section 3.3). Further research would be needed to better understand the role of each process in the increase of adsorbed $\mathrm{Hg}$ in $\mathrm{Hg}$-exposed communities.

No direct relationship between $\{\mathrm{MeHg}\}_{n-e x t}$ and $\mathrm{Hg}$ concentrations in the culture media could be established and the maximal $\{\mathrm{MeHg}\}_{n-e x t}\left(19.60 \mathrm{pmol} \mathrm{g}_{\mathrm{dw}}{ }^{-1}\right)$ was found in the control biofilms, representing $5.9 \%$ of $\{\mathrm{THg}\}$ (Figure $1 \mathrm{II})$. A decrease in the fraction of $\{\mathrm{MeHg}\}_{n \text {-ext }}$ as compared to $\{\mathrm{THg}\}$ was observed with the increase of $\mathrm{Hg}$ cultivation concentration, with values of $1.6 \%, 0.29 \%$, and $0.08 \%$ in biofilms exposed to $11 \mathrm{pM}, 121 \mathrm{pM}$ and $1454 \mathrm{pM}$, respectively, reflecting the large increase in $\{\mathrm{THg}\}$. Such low percentage of $\{\mathrm{MeHg}\}_{\text {n-ext }}$ was also found in biofilms grown in Hg-contaminated reservoirs [19]. That lack of $\{\mathrm{MeHg}\}_{\text {n-ext }}$ increase found in the present study with the increase of culture $\mathrm{Hg}$ concentrations contrasts with the large body of evidence reporting methylation occurring in biofilms [15,36,37]. However, comparison is difficult to make since only the total bioaccumulated $\mathrm{MeHg}$ (adsorbed + absorbed) as well as the production of MeHg in the exposure media are usually measured.

Overall, our measured concentrations of bioaccumulated $\mathrm{Hg}$ were found to be representative of those encountered in natural environments, even at the highest dissolved $\mathrm{Hg}$ culture concentrations.

\subsection{Hg Impacts on Biofilms}

\subsubsection{Biofilm Biomass}

The effects of $\mathrm{Hg}$ on substrata colonisation by biofilms were firstly examined by determining the biofilm chlorophyll content, their biomass, and the surface coverage of the substrata (Figure 2). The 
chlorophyll content of the control biofilm was $3.7 \pm 0.6 \mathrm{ng} \mathrm{cm}^{-2}$ and was observed to be significantly higher upon cultivation in $11 \mathrm{pM} \mathrm{Hg}\left(7.0 \pm 0.7 \mathrm{ng} \mathrm{cm}^{-2}\right)$ and $121 \mathrm{pM} \mathrm{Hg}\left(7.5 \pm 1.1 \mathrm{ng} \mathrm{cm}^{-2}\right)$. A decrease back to comparative levels $\left(5.4 \pm 0.5 \mathrm{ng} \mathrm{cm}^{-2}\right)$ than the control was observed at $1454 \mathrm{pM} \mathrm{Hg}$ (Figure 2I). The photosynthetic system is a well-known target of $\mathrm{Hg}$ in phototrophic organisms, leading to a decrease of chlorophyll $a$ concentration [38,39], but at much higher $\mathrm{Hg}$ concentrations $(\sim \mu \mathrm{M})$ than those studied in the present study. Moreover, IHg has been shown to have beneficial properties as electron acceptors for photomixotrophs in limited $\mathrm{CO}_{2}$ conditions, suggesting that the photosynthetic system might not be impacted under certain conditions [40]. As such, the possible effects of $\mathrm{Hg}$ growing concentrations towards photosynthetic bacteria and microalgae may not detectable in the present study using the chlorophyll content. No significant difference was observed in the AFDM of the control and Hg-culture biofilms (Figure 2II). The surface coverage of the substrata for biofilms grown under control conditions $(7.5 \pm 2.5 \%)$ and in $11 \mathrm{pM} \mathrm{Hg}(7.5 \pm 1.9 \%)$ were low (Figure 2III), which was accentuated at the two highest $\mathrm{Hg}$ concentrations with values at $4.6 \pm 2.5 \%$ and $3.3 \pm 2.6 \%$ for biofilms grown in $121 \mathrm{pM}$ and $1454 \mathrm{pM}$, respectively. Lower surface coverage was also observed in biofilms growing in reservoirs contaminated with $\mathrm{Hg}$ as compared to biofilms collected in upstream site and in less-Hg contaminated reservoirs [19]. The biotic (including all organisms harbored in biofilms) and abiotic fractions (all inert particles within biofilm) were comparable among biofilms (Figure 2IV).

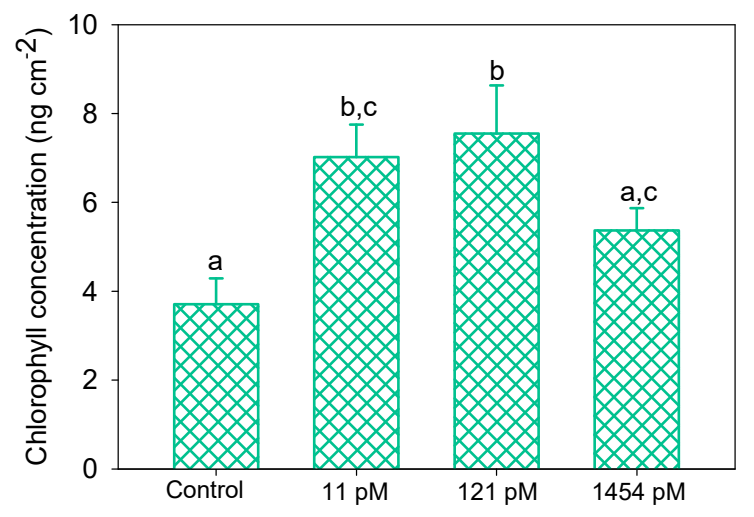

(I)

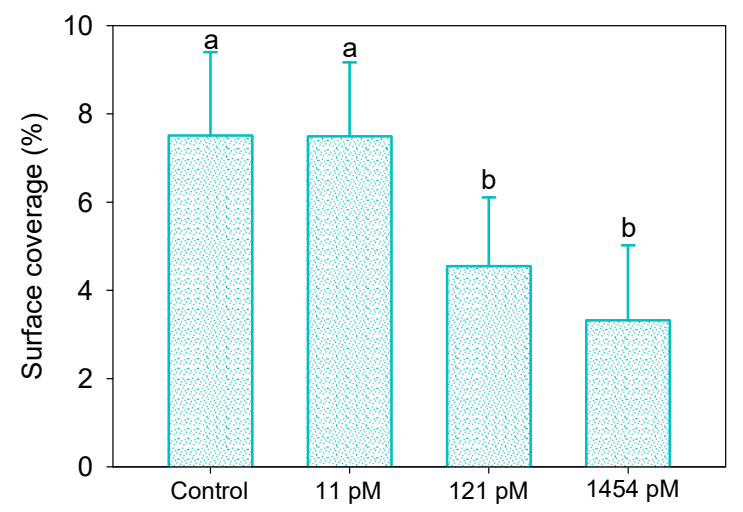

(III)

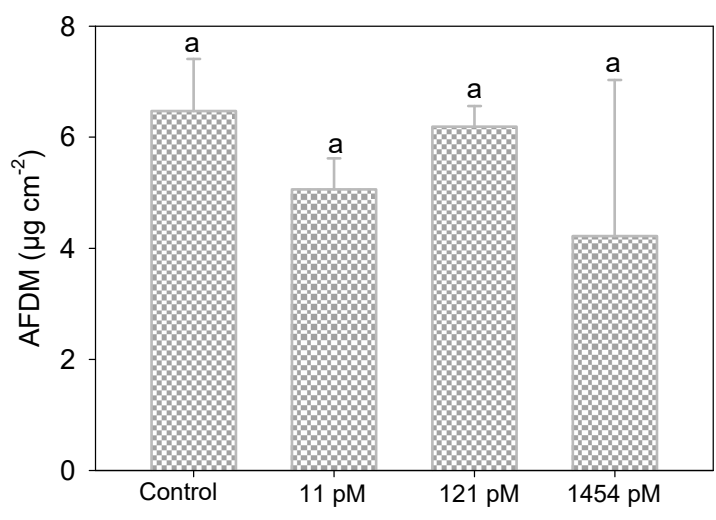

(II)

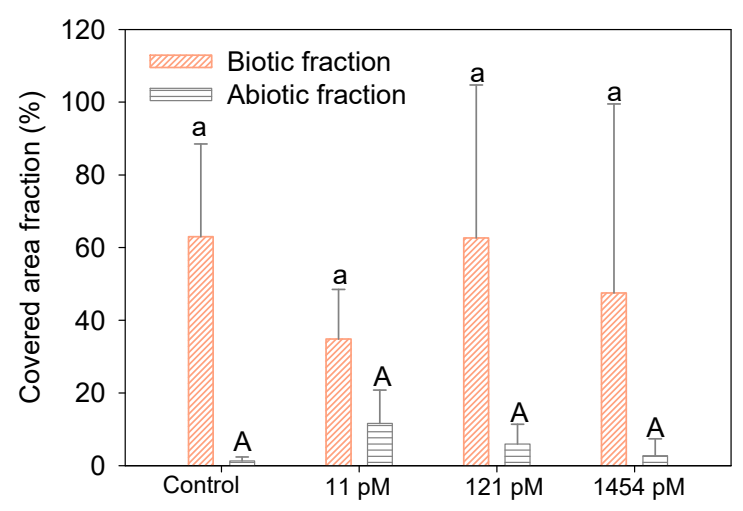

(IV)

Figure 2. Composition of the control biofilm and biofilms grown in $11 \pm 2 \mathrm{pM}, 121 \pm 9 \mathrm{pM}$ and $1454 \pm 54$ pM Hg; (I) chlorophyll concentration ( $n=3)$, (II) ash-free dry weight (AFDM) $(n=3)$, (III) surface coverage area $(n=10)$ and (IV) abiotic and biotic fractions $(n=10)$. Letters $(\mathrm{a}, \mathrm{b}, \mathrm{c}$ and A) indicate significant differences between treatments for the studied characteristics $(p<0.05)$. 


\subsubsection{Bacterial Biofilm Composition}

Bacterial community composition of the studied biofilms was determined by amplicon sequencing. Their OTUs richness was found to increase with $\mathrm{Hg}$ cultivation concentrations, from 209 in the control biofilms to 291 in biofilms exposed to the highest $\mathrm{Hg}$ concentration. That result can be partly explained by the increase of measured total sequences from 1269 to 45,251, also observed with $\mathrm{Hg}$ concentrations (Table 1). Indeed, standardization of the richness index with the calculation of the rarefied richness demonstrated that the bacterial species richness remained comparable to the control at the highest $\mathrm{Hg}$ concentration (rarefaction curves are presented in Figure S2I). Nevertheless, a decrease could be observed in the biofilms grown in $11 \mathrm{pM}$ and $121 \mathrm{pM}$ treatment. That observation is in line with our previous field study showing the higher richness of bacteria in the contaminant-affected reservoirs vs the uncontaminated reservoir [20]. The Simpson's diversity index was found to be very high for all the bacterial communities (mean value of 0.96) and similar among microcosms, demonstrating that the studied bacterial communities were very diverse and that the most frequent taxa were equally distributed, without dominant OTUs. Moreover, their turnover indicated that their diversity remains insensitive to $\mathrm{Hg}$ concentrations.

Table 1. Total sequences, OTUs and rarefied richness, Simpson's diversity index and species turnover for bacteria and microalgae communities in biofilms grown without $\mathrm{Hg}$ addition (control), in $11 \pm 2 \mathrm{pM}$, $121 \pm 9 \mathrm{pM}$ and $1454 \pm 54 \mathrm{pM} \mathrm{Hg}$.

\begin{tabular}{|c|c|c|c|c|c|}
\hline Taxa & Parameters & Control & $11 \mathrm{pM}$ & $121 \mathrm{pM}$ & $1454 \mathrm{pM}$ \\
\hline \multirow[t]{5}{*}{ Bacteria } & Total sequences & 1269 & 21,441 & 25,731 & 45,251 \\
\hline & OTUs richness & 209 & 224 & 229 & 291 \\
\hline & Rarefied richness & $209 \pm 1$ & $191 \pm 4$ & $180 \pm 5$ & $210 \pm 6$ \\
\hline & Simpson's index & 0.97 & 0.96 & 0.94 & 0.97 \\
\hline & Species turnover ${ }^{1}$ & - & 0.65 & 0.63 & 0.63 \\
\hline \multirow[t]{5}{*}{ Algae } & Total sequences & 12023 & 2006 & 5624 & 1520 \\
\hline & OTUs richness & 71 & 48 & 63 & 48 \\
\hline & Rarefied richness & $56 \pm 2$ & $46 \pm 1$ & $50 \pm 5$ & $48 \pm 1$ \\
\hline & Simpson's index & 0.87 & 0.77 & 0.92 & 0.85 \\
\hline & Species turnover ${ }^{1}$ & - & 0.41 & 0.28 & 0.37 \\
\hline
\end{tabular}

Thirty-eight OTUs were unique to the control biofilm, which represented $10 \%$ of the total bacteria abundance. That percentage of unique OTUs remained low in the Hg-exposed biofilms with values ranging between $3 \%$ and $5 \%$ (Figure $3 \mathrm{I}$ ). As a consequence, the percentage of shared OTUs was high and represented 55\% (control) to $71 \%(121 \mathrm{pM} \mathrm{Hg})$ of the total abundance. The Proteobacteria were the most abundant phyla, with a proportion that increased upon $\mathrm{Hg}$ concentrations, e.g., from $68 \%$ in the control biofilms to a maximum of $86 \%$ in biofilms exposed to $121 \mathrm{pM} \mathrm{Hg}$ (Figure 3II).

In that phylum, the Betaproteobacteria was the most abundant class, representing $19 \%$ of the total abundance in the control. That proportion increased with the increase of $\mathrm{Hg}$ culture concentration, representing 38\%, 47\% and 40\%, of the total class in the biofilms grown in $11 \mathrm{pM}, 121 \mathrm{pM}$, and 1454 pM Hg, respectively (Table S2I). The observed sensitivity of Proteobacteria to $\mathrm{Hg}$ is in agreement with a recent study showing that the largest variation observed among taxa in microbial communities exposed to 250 pM Hg concerned Proteobacteria [41]. Additionally, the percentage of Bacteroidetes, Actinobacteria, Verrucomicrobia, and Cyanobacteria decreased upon cultivation in $\mathrm{Hg}$ (Figure 3II). These results contrast with those findings suggesting that Cyanobacteria and Bacteroidetes were tolerant to $\mathrm{Hg}[20,42,43]$ and demonstrate that the species of Cyanobacteria and Bacteroidetes present in the studied biofilms were not tolerant to $\mathrm{Hg}$. 


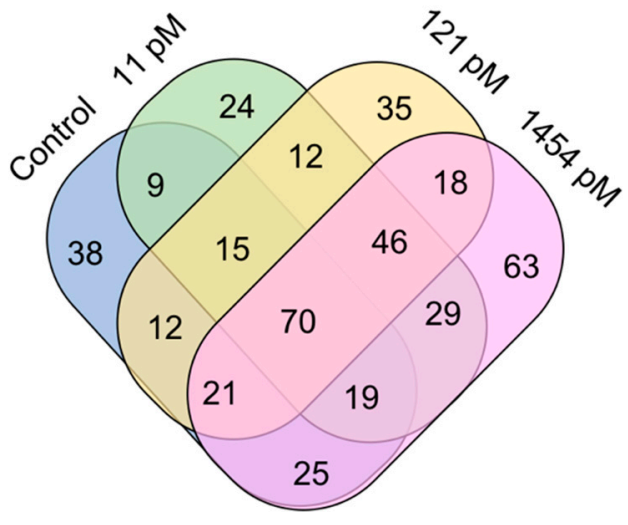

(I)

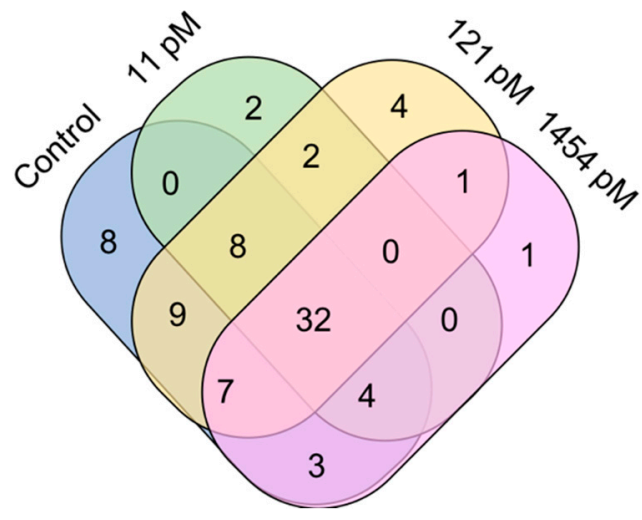

(III)

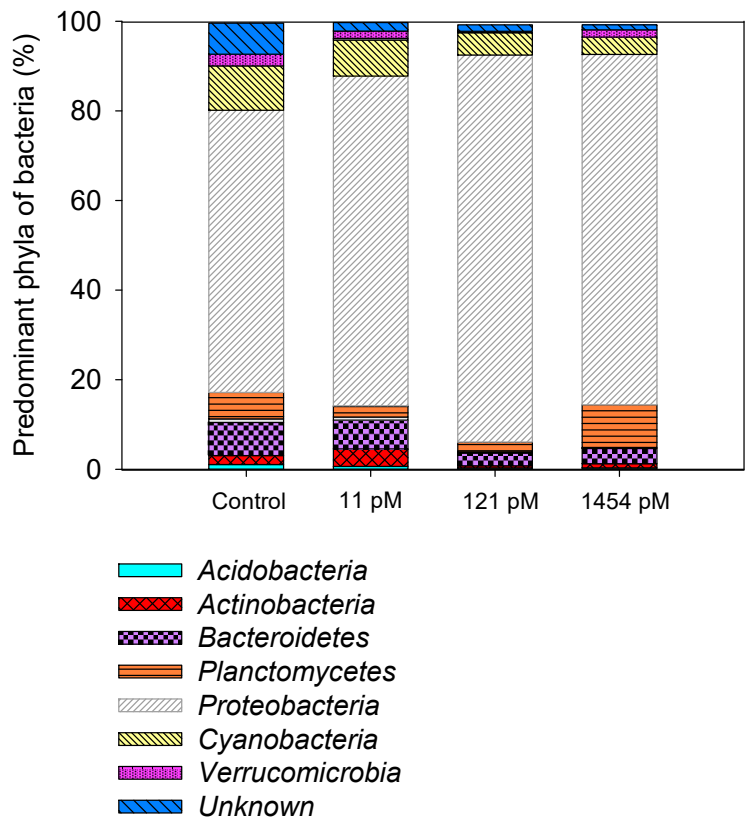

(II)

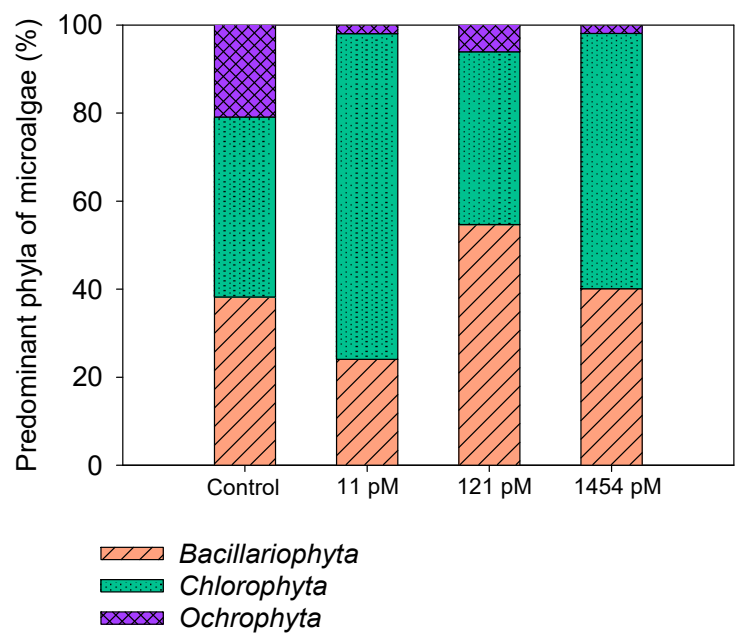

(IV)

Figure 3. Venn diagram showing the shared and specific OTUs between control biofilm and biofilms grown in $11 \pm 2 \mathrm{pM}, 121 \pm 9 \mathrm{pM}$, and $1454 \pm 54 \mathrm{pM} \mathrm{Hg}$ and their composition at the phylum level; (I) and (II) bacteria, respectively, and (III) and (IV) microalgae, respectively.

\subsubsection{Algal Biofilm Composition}

The total sequences corresponding to algal communities decreased upon $\mathrm{Hg}$ exposure, which was accompanied by the decrease of the OTUs richness (Table 1). However, in contrast to the bacteria, the rarefied richness was also lower in $\mathrm{Hg}$-grown biofilms than in control biofilms, suggesting that those low $\mathrm{Hg}$ concentrations impacted the algal community richness of our studied biofilms (the rarefaction curves are presented in Figure S2II). The studied algal communities were very diverse with an averaged Simpson's diversity index of 0.85 and was not affected by the cultivation in $\mathrm{Hg}$, except at $11 \mathrm{pM}$ exposed biofilms, which had a calculated index of 0.77 . This result suggests that the microalgal community grown at $11 \mathrm{pM}$ was more heterogeneous. Finally, both biofilms grown in $11 \mathrm{pM}$ and $1454 \mathrm{pM} \mathrm{Hg}$ had a higher turnover than those grown in $121 \mathrm{pM}$, making it difficult to conclude on $\mathrm{Hg}$ effects on the $\beta$-diversity of the studied algal communities. Note that the bacteria turnover values 
were higher than those of algae, suggesting that the bacteria reacted more rapidly to Hg exposure than algae.

Eight OTUs assigned to microalgae were specific to the control biofilm $(0.6 \%$ of the total abundance) (Figure 3III). Again, that percentage remained low in Hg-grown biofilms with values of $0.4 \%, 4 \%$ and $0.2 \%$ in $11 \mathrm{pM}, 121 \mathrm{pM}$, and $1454 \mathrm{pM} \mathrm{Hg}$. In total, 32 OTUs were shared among the biofilms, representing $92 \%, 96 \%, 88 \%$, and $92 \%$ of the total abundance in the control biofilm and those cultivated in $11 \mathrm{pM}, 121 \mathrm{pM}$, and $1454 \mathrm{pM} \mathrm{Hg}$, respectively. For each biofilm, microalgal communities were dominated by three phyla, i.e., Bacillariophyta, Chlorophyta, and Ochrophyta (Figure 3IV). However, the percentage of Ochrophyta decreased in each biofilm grown in Hg whereas Chlorophyta increased in microcosms containing $11 \mathrm{pM}$ and $1454 \mathrm{pM}$, except in biofilms exposed to $121 \mathrm{pM}$ (Table S2II). The disappearance of Ochrophyta was also observed in the field with the degradation of the water quality concomitant with an increase of $\mathrm{Hg}$ concentration [20].

\section{Conclusions}

The present study presents our first results on the influence of the long-term $\mathrm{Hg}$ exposure to bacterial and microalgal biofilm communities. The low $\mathrm{Hg}$ concentration increase in the biofilm culture media (up to $1454 \mathrm{pM}$ ) resulted in the enhancement of $\mathrm{Hg}$ accumulation in biofilms, and for both total and non-extractable fractions. That $\mathrm{Hg}$ bioaccumulation did not negatively affect the biofilm chlorophyll content, neither their AFDM, but a decrease of the surface coverage of the substrata (used as a proxy for biofilm growth) was measured. Additionally, the richness and diversity of the bacterial communities were not affected by $\mathrm{Hg}$, whereas modification could be observed at the phyla level with an increase of Proteobacteria and a decrease of Bacteroidetes, Actinobacteria, Verrucomicrobia, and Cyanobacteria. A stronger impact was observed on algal communities with a decrease of their rarefied richness with $\mathrm{Hg}$ concentrations. The communities were dominated by Chlorophyta and Bacillariophyta under all treatments, while the Ochrophyta significantly decreased in the Hg-enriched microcosms. That algal sensitivity to $\mathrm{Hg}$ might be an asset to develop biomonitoring tools to assess the degradation of water quality by $\mathrm{Hg}$ in the field but will need to be confirmed through additional long-term experiments using complementary $\mathrm{Hg}$ treatment and replicates.

Supplementary Materials: The following are available online at http:/ /www.mdpi.com/2076-3298/6/3/28/s1, Figure S1: Measured mercury concentration in microcosms at the beginning of the exposure (measured after $\mathrm{Hg}$ addition, Day 0) and after 5, 33 and 55 days of cultivation, Figure S2: Rarefaction curves from the amplicon sequencing of (I) bacteria and (II) microalgae in control biofilm and in biofilms grown in $11 \pm 2 \mathrm{pM}, 121 \pm 9 \mathrm{pM}$ and $1454 \pm 54 \mathrm{pM} \mathrm{Hg}$ for 55 days, Table S1: Average $\mathrm{pH}$, temperature and concentration of dissolved organic carbon, trace metals and major anions/cations of the Geneva Lake water $( \pm \mathrm{SD}, n=3)$, Table S2: Taxonomic ranks of the major microorganisms living in biofilms as well as the number of sequences and their abundance (\%) calculated with OTUs assigned to (I) bacteria and (II) microalgae after 50 days of exposure to IHg. The abundance was calculated by dividing the specific number of sequences assigned to an OTU to the total number of sequences, multiplied by 100 .

Author Contributions: S.L.F. initiated the study; P.D., A.F. and S.L.F. designed the experiments; A.F. and P.D. carried out the experiments; A.F., P.D. and S.L.F. performed data analyses; P.D., S.L.F. and V.I.S. discussed the obtained results; P.D. wrote the first draft of the paper; S.L.F. wrote, reviewed and edited the final version; P.D. and V.I.S. reviewed the draft and final versions.

Funding: This research was funded by the Swiss National Science Foundation, grant number IZERZO-142228.

Acknowledgments: We gratefully thank Valérie Parietti for technical assistance and Dorothea Hug Peter for her help to interpret the ecological indexes.

Conflicts of Interest: The authors declare no conflict of interest.

\section{References}

1. Battin, T.J.; Besemer, K.; Bengtsson, M.M.; Romani, A.M.; Packmann, A.I. The ecology and biogeochemistry of stream biofilms. Nat. Rev. Microbiol. 2016, 14, 251-263. [CrossRef] [PubMed]

2. Vannote, R.L.; Minshall, G.W.; Cummins, K.W.; Sedell, J.R.; Cushing, C.E. River continuum concept. Can. J. Fish. Aquat. Sci. 1980, 37, 130-137. [CrossRef] 
3. Azim, M.E. Photosynthetic periphyton and surfaces. In Encyclopedia of Inland Waters; Likens, G.E., Ed.; Academic Press: Oxford, UK, 2009; pp. 184-191.

4. Lear, G.; Dopheide, A.; Ancion, P.-Y.; Roberts, K.V.W.; Smith, J.G.; Lewis, G.D. Biofims in freshwater: Their importance for maintenance and monitoring of freshwater health. In Microbial Biofilms: Current Research and Applications; Lear, G., Lewis, G.D., Eds.; Caiser Academic Press: Norfolk, UK, 2012; pp. 129-152.

5. Sabater, S.; Guasch, H.; Ricart, M.; Romani, A.; Vidal, G.; Kluender, C.; Schmitt-Jansen, M. Monitoring the effect of chemicals on biological communities. The biofilm as an interface. Anal. Bioanal. Chem. 2007, 387, 1425-1434. [CrossRef] [PubMed]

6. Burns, A.; Ryder, D.S. Potential for biofilms as biological indicators in Australian riverine systems. Ecol. Manag. Restor. 2001, 2, 53-64. [CrossRef]

7. Amos, H.M.; Jacob, D.J.; Streets, D.G.; Sunderland, E.M. Legacy impacts of all-time anthropogenic emissions on the global mercury cycle. Glob. Biogeochem. Cycles 2013, 27, 410-421. [CrossRef]

8. Lamborg, C.H.; Hammerschmidt, C.R.; Bowman, K.L.; Swarr, G.J.; Munson, K.M.; Ohnemus, D.C.; Lam, P.J.; Heimburger, L.E.; Rijkenberg, M.J.A.; Saito, M.A. A global ocean inventory of anthropogenic mercury based on water column measurements. Nature 2014, 512, 65-67. [CrossRef] [PubMed]

9. Dranguet, P.; Le Faucheur, S.; Slaveykova, V.I. Mercury bioavailability, transformations, and effects on freshwater biofilms. Environ. Toxicol. Chem. 2017, 36, 3194-3205. [CrossRef] [PubMed]

10. Dominique, Y.; Maury-Brachet, R.; Muresan, B.; Vigouroux, R.; Richard, S.; Cossa, D.; Mariotti, A.; Boudou, A. Biofilm and mercury availability as key factors for mercury accumulation in fish (Curimata cyprinoides) from a disturbed Amazonian freshwater system. Environ. Toxicol. Chem. 2007, 26, 45-52. [CrossRef] [PubMed]

11. Cremona, F.; Hamelin, S.; Planas, D.; Lucotte, M. Sources of organic matter and methylmercury in littoral macroinvertebrates: A stable isotope approach. Biogeochemistry 2009, 94, 81-94. [CrossRef]

12. Cheng, J.P.; Zhao, W.C.; Liu, Y.Y.; Wu, C.; Liu, C.; Wang, W.H. Adsorption properties and gaseous mercury transformation rate of natural biofilm. Bull. Environ. Contam. Toxicol. 2008, 81, 516-520. [CrossRef] [PubMed]

13. Hamelin, S.; Amyot, M.; Barkay, T.; Wang, Y.P.; Planas, D. Methanogens: Principal methylators of mercury in lake periphyton. Environ. Sci. Technol. 2011, 45, 7693-7700. [CrossRef] [PubMed]

14. Correia, R.R.S.; Miranda, M.R.; Guimaraes, J.R.D. Mercury methylation and the microbial consortium in periphyton of tropical macrophytes: Effect of different inhibitors. Environ. Res. 2012, 112, 86-91. [CrossRef] [PubMed]

15. Bouchet, S.; Goni-Urriza, M.; Monperrus, M.; Guyoneaud, R.; Fernandez, P.; Heredia, C.; Tessier, E.; Gassie, C.; Point, D.; Guedron, S.; et al. Linking microbial activities and low-molecular-weight thiols to $\mathrm{Hg}$ methylation in biofilms and periphyton from high-altitude tropical lakes in the Bolivian altiplano. Environ. Sci. Technol. 2018, 52, 9758-9767. [CrossRef] [PubMed]

16. Peres, E.; Coste, M.; Ribeyre, F.; Ricard, M.; Boudou, A. Effects of methylmercury and inorganic mercury on periphytic diatom communities in freshwater indoor microcosms. J. Appl. Phycol. 1997, 9, 215-227. [CrossRef]

17. Val, J.; Muniz, S.; Goma, J.; Navarro, E. Influence of global change-related impacts on the mercury toxicity of freshwater algal communities. Sci. Total Environ. 2016, 540, 53-62. [CrossRef] [PubMed]

18. Kovac Virsek, M.; Hubad, B.; Lapanje, A. Mercury induced community tolerance in microbial biofilms is related to pollution gradients in a long-term polluted river. Aquat. Toxicol. 2013, 144-145C, $208-217$. [CrossRef] [PubMed]

19. Dranguet, P.; Le Faucheur, S.; Cosio, C.; Slaveykova, V.I. Influence of chemical speciation and biofilm composition on mercury accumulation by freshwater biofilms. Environ. Sci. Processes Impacts 2017, 19, 38-49. [CrossRef] [PubMed]

20. Dranguet, P.; Cosio, C.; Le Faucheur, S.; Hug-Peter, D.; Loizeau, J.L.; Ungureanu, V.G.; Slaveykova, V.I. Biofilm composition in the Olt River (Romania) reservoirs impacted by a chlor-alkali production plant. Environ. Sci. Processes Impacts 2017, 19, 687-695. [CrossRef] [PubMed]

21. USEPA. Method 1631, Revision E: Mercury in Water by Oxidation, Purge and Trap, and Cold Vapor Atomic Fluorescence Spectrometry; EPA: Washington, DC, USA, 2002; p. 38.

22. Dranguet, P.; Slaveykova, V.I.; Le Faucheur, S. Kinetics of mercury accumulation by freshwater biofilms. Environ. Chem. 2018, 14, 458-467. [CrossRef]

23. Rasband, W.S. ImageJ; U.S. National Institutes of Health: Bethesda, MD, USA, 1997-2018. Available online: https:/ / imagej.nih.gov/ij/ (accessed on 21 February 2019). 
24. Zimmermann, J.; Jahn, R.; Gemeinholzer, B. Barcoding diatoms: Evaluation of the V4 subregion on the $18 \mathrm{~S}$ rRNA gene; including new primers and protocols. Org. Divers. Evol. 2011, 11, 173-192. [CrossRef]

25. Bricheux, G.; Morin, L.; Le Moal, G.; Coffe, G.; Ballestrino, D.; Charbonnel, N.; Bohatier, J.; Forestier, C. Pyrosequencing assessment of prokaryotic and eukaryotic diversity in biofilm communities from a French river. Microbiologyopen 2013, 2, 402-414. [CrossRef] [PubMed]

26. Anderson, M.J.; Crist, T.O.; Chase, J.M.; Vellend, M.; Inouye, B.D.; Freestone, A.L.; Sanders, N.J.; Cornell, H.V.; Comita, L.S.; Davies, K.F.; et al. Navigating the multiple meanings of beta diversity: A roadmap for the practicing ecologist. Ecol. Lett. 2011, 14, 19-28. [CrossRef] [PubMed]

27. Clark, K.; Karsch-Mizrachi, I.; Lipman, D.J.; Ostell, J.; Sayers, E.W. GenBank. Nucleic Acids Res. 2016, 44, D67-D72. [CrossRef] [PubMed]

28. Oksanen, J.; Blanchet, F.G.; Kindt, R.; Legendre, P.; Minchin, P.R.; O’Hara, R.B.; Simpson, G.L.; Solymos, P.; Stevens, M.H.H.; Wagner, H. Vegan: Community Ecology Package. R Package Version 2.3-3. 2016. Available online: http:/ / cran.r-project.org/package=vegan (accessed on 1 December 2018).

29. Van de Peer Lab, Bioinformatics and Evolutionary Genome, 2018. Available online: http:/ / bioinformatics. psb.ugent.be/beg/software?page=2 (accessed on 1 December 2018).

30. R Core-Team. A Language and Environment for Statistical Computing; R Foundation for Statistical Computing: Vienna, Austria, 2015.

31. CIPEL. Rapports de la Commission Internationale pour la Protection des eaux du Léman Contre la Pollution-Campagne 2013; CIPEL: Nyon, Switzerland, 2014.

32. Brenda, K.; Lasorsa, G.A.G.; Horvat, M. Analytical methods for measuring mercury in water, sediment and Biota. In Mercury in the Environment; Bank, M.S., Ed.; University of California Press: Berkeley, CA, USA, 2012; pp. 27-54.

33. Žižek, S.; Milacic, R.; Kovac, N.; Jacimovic, R.; Toman, M.J.; Horvat, M. Periphyton as a bioindicator of mercury pollution in a temperate torrential river ecosystem. Chemosphere 2011, 85, 883-891. [CrossRef] [PubMed]

34. Osborn, A.M.; Bruce, K.D.; Strike, P.; Ritchie, D.A. Distribution, diversity and evolution of the bacterial mercury resistance (mer) operon. FEMS Microbiol. Rev. 1997, 19, 239-262. [CrossRef] [PubMed]

35. Dash, H.R.; Das, S. Interaction between mercuric chloride and extracellular polymers of biofilm-forming mercury resistant marine bacterium Bacillus thuringiensis PW-05. RSC Adv. 2016, 6, 109793-109802. [CrossRef]

36. Hamelin, S.; Planas, D.; Amyot, M. Mercury methylation and demethylation by periphyton biofilms and their host in a fluvial wetland of the St. Lawrence River (QC; Canada) Sci. Total Environ. 2015, 512-513, 464-471. [CrossRef] [PubMed]

37. Olsen, T.A.; Brandt, C.C.; Brooks, S.C. Periphyton biofilms influence net methylmercury production in an industrially contaminated system. Environ. Sci. Technol. 2016, 50, 10843-10850. [CrossRef] [PubMed]

38. Murthy, S.D.S.; Bukhov, N.G.; Mohanty, P. Mercury induced alterations of chlorophyll a fluorescence kinetics in Cyanobacteria-Multiple effects of mercury on electron transport. J. Photochem. Photobiol. Biol. 1990, 6, 373-380. [CrossRef]

39. Kampnielsen, L. Effect of deleterious concentrations of mercury on photosynthesis and growth of Chlorella pyrenoidosa. Physiol. Plant. 1970, 24, 556-561. [CrossRef]

40. Grégoire, D.S.; Poulain, A.J. A physiological role for Hg-II during phototrophic growth. Nat. Geosci. 2016, 9 , 121-127. [CrossRef]

41. Hiller-Bittrolff, K.; Foreman, K.; Bulseco-McKim, A.N.; Benoit, J.; Bowen, J.L. Effects of mercury addition on microbial community composition and nitrate removal inside permeable reactive barriers. Environ. Pollut. 2018, 242, 797-806. [CrossRef] [PubMed]

42. Rasmussen, L.D.; Zawadsky, C.; Binnerup, S.J.; Oregaard, G.; Sorensen, S.J.; Kroer, N. Cultivation of hard-to-culture subsurface mercury-resistant bacteria and discovery of new merA gene sequences. Appl. Environ. Microbiol. 2008, 74, 3795-3803. [CrossRef] [PubMed]

43. Lazaro, W.L.; Guimaraes, J.R.D.; Ignacio, A.R.A.; Da Silva, C.J.; Diez, S. Cyanobacteria enhance methylmercury production: A hypothesis tested in the periphyton of two lakes in the Pantanal floodplain, Brazil. Sci. Total Environ. 2013, 456-457, 231-238. [CrossRef] [PubMed] 